Article

\title{
Terrorism as a Determinant of Attracting FDI in Tourism: Panel Analysis
}

\author{
Maja Nikšić Radić(i) \\ Department of International Economics and Development, Faculty of Tourism and Hospitality Management, \\ University of Rijeka, 51410 Opatija, Croatia; majanr@fthm.hr
}

Received: 15 October 2018; Accepted: 21 November 2018; Published: 3 December 2018

check for updates

\begin{abstract}
The aim of this paper is to investigate whether terrorism is one of the important determinants affecting the investment decisions of foreign investors in tourism on a panel of 50 countries over the period 2000 to 2016. In addition to terrorism, the importance of three other theoretically significant determinants of attracting foreign direct investment $(F D I)$ in tourism are explored-the previous level of FDI in tourism, the level of GDP and the international tourist arrivals. To obtain more reliable research results, the initial model is extended with certain control variables. The study uses system-GMM estimator for dynamic panel data models. The research results of a narrower and a wider model indicate that terrorism has no significant effect on the FDI inflow in tourism while international tourist arrivals significantly affect the future $F D I$ in tourism in both models. Furthermore, the research results entail certain political connotations. In order to attract foreign investors in tourism, the most important factor is to ensure a stable macroeconomic environment with a competitive position in the Doing Business list and what better business conditions. Attention should also be focused on the security and preventive counter-terrorism, which will ensure that potential destinations reflect confidence, have a growth rate of tourist arrivals and, consequently, attract foreign investors.
\end{abstract}

Keywords: terrorism; FDI in tourism; SYS-GMM estimator

\section{Introduction}

Already at the beginning of this century, tourism has become the largest worldwide industry and its development continues [1]. According to World Tourism Organizatin's World Tourism Barometer, in 2018, international tourist arrivals grew by 7\% in 2017 and reached 1322 million. This figure will reach 1.8 billion by 2030 [2]. Moreover, in 2017, tourism is shown to account for $10.4 \%$ of global GDP and $9.9 \%$ of total employment [3].

FDI (foreign direct investment) in tourism is very important for the further development of tourism, especially in the developing and less developed countries [4,5]. FDI enables host countries to be integrated into international tourism networks which will lead to increases in the flow of tourists and the generation of more income from tourism-related activities [6]. Tourism also strongly contributes to foreign exchange earnings, national income and job creation [7]. As far as FDI in tourism is concerned, from 2003 to 2016, \$352 billion in capital expenditure was spent on tourism, and from 39 sectors, tourism ranked 10th in terms of capital investment [5].

Today, the number of terrorist attacks is much higher than it was at the end of the 20th century. According to [8], the peak was reached in 2014 when it recorded about 17,000 attacks, however the latest data show that since then, the number of terrorist attacks is still decreasing and in 2017, it amounted to about 11,000 attacks.

Tourism and FDI are two significant forces affecting the economy of many countries. They are also related to each other because the further development of tourism strongly depends on FDI in 
tourism $[9,10]$. Simultaneously, during the 21st century, terrorism has become a very significant threat to global business and, thus, to FDI and tourism.

It is necessary to highlight in the context of this research that tourism is extremely volatile. Bearing in mind terrorism as a serious globalization challenge facing the world today and the volatility of tourism, the question is whether terrorism affects attracting foreign investors to tourism. The main aim of this paper is to investigate whether terrorism, with the previous level of FDI in tourism, the level of GDP and the number of international tourist arrivals, is a significant determinant of attracting $F D I$ in tourism. In addition, to ensure the reliability of the research results, the research includes certain specific control variables such as control of corruption, index of political stability and the Doing Business index.

Bearing in mind the above-mentioned aim of this research, the author bases this research on a hypothesis that claims that terrorism is not a significant determinant of $F D I$ in tourism. The survey was carried out involving a panel of 50 countries for the period 2000 to 2016. It is possible to highlight several key arguments in favor of the set hypothesis. Considering the interdependence between tourism supply and tourism demand [11], the first argument in favor of the hypothesis applies to tourist demand. Terrorism has been proven to have no significant impact on tourist decision-making, and [12] argue that tourists should not unnecessarily be concerned about terrorism. It has been proven, in the case of the African countries, that the long-term increase in political risk is associated with an increase in revenues from tourism [13]. Finally, tourism is increasingly dominated by the development of some of its selective forms, such as dark tourism. It is about tourists who are attracted by the terrorist danger in the terrorism-affected destination [14]. Also, it is needless to emphasize that international tourist arrivals are experiencing continuous growth and this trend is expected in the future as well [2]. The second argument concerns the tourism supply. Given that tourism supply responds to tourism demand, it is logical to expect that terrorism will not affect FDI in tourism. FDI in tourism is mainly focused on hotel business [6], which is very capital-intensive. Holders of such investments are aware of the possibility of a terrorism risk and they deal with it as with other types of business risks-they identify it, evaluate it and then manage it [15]. According to [16], terrorism is a low probability - high impact risks and the results of existing research indicate that foreign property owners usually underestimate the vulnerability of buildings to a terrorist attack. However, such reactions are expected, as data from the hotel and tourism industry point to the fact that hotel business returns to normal three months after an attack, as long as there were no further attacks [17].

International terrorism is certainly one of the greatest risks that internationally active corporations may face [18]. Globalization due to terrorism will not stop, however it will probably become more expensive and slower because of the need for insurance against terrorism, stricter border controls and immigration policies [19]. This impression is confirmed in the last decade because there has been a change of mentality between consumers and corporations that in response to terrorism, they are beginning to behave normally [20]. It should also be noted that, according to [21], investors in different sectors react differently and their ability to absorb or reduce future risks is influenced by numerous other economic and political factors. The fact is that, for example, international hotels are the symbolic targets of Western wealth and influence that attract the kind of militants who want to eliminate foreigners, business travelers, tourists and the local elite [22]. On the other hand, tourism is a very resilient sector and it takes only 13 months for tourism to recover from a terrorist attack [23].

The following section provides some stylized facts about the relationship between terrorism and FDI. Section 3 describes the data and the methodological framework of the research, while Section 4 shows the results and discussion of the conducted empirical research. Finally, a conclusion and policy implications are drawn in Section 5. 


\section{State-of-the-Art: Relationship between Terrorism and FDI}

Despite the current importance of terrorism on a global scale, the role of terrorism as a determinant of attracting FDI has not yet been fully explored in the literature. At the same time, in the available literature, it is apparent that the results of the influence of terrorism on FDI are unambiguous.

One stream of the research suggests a negative impact of terrorism on FDI. There is certainly a need to highlight mature research such as [24,25]. In the period from 1975 to 1991, terrorism, on average, reduced the net inflow of $F D I$ to Spain by $13.5 \%$ and Greece by $11.9 \%$ [24]. Ref. [25], with the example of the Basque Country, a region of Spain, found no indications that entrepreneurs left Spain because of terrorist activities, however they assumed that terrorism had caused Spain's negative reputation. Consequently, this may have directed foreign investors to some other destinations. The same authors, however in 2008 and on the example of the USA, pointed out that the standard deviation increase in the terrorist risk leads to a 5\% decline in the net FDI [26]. Ref. [27] on the panel of 136 developing countries ascertained the negative impact of terrorism on FDI. Ref. [21] corroborates that transnational terrorism negatively affects the total inflow of FDI in advanced countries. Ref. [28] with the example of the selected EU and EEA countries, demonstrates that terrorist activities reduce the security and confidence of investors in countries that are exposed to terrorist activities, thus reducing the FDI inflow. The same inferences come from $[29,30]$.

The other stream of research suggests possible contradictions related to the impact of terrorism on FDI. Even in 1983, terrorism generally did not significantly affect $F D I$, although it had significant localized impacts in places such as the Basque region in Spain or Northern Ireland [31]. Thus, ref. [32] with the example of OECD countries demonstrate the negative impact of terrorism on FDI, however they also point to the fact that the impact of terrorism on FDI in OECD non-member countries is insignificant. Furthermore, insignificant results related to the correlation of terrorism and FDI are found in [33]. Ref. [34] indicates that business terrorism has had a negative impact on FDI, while the impact of terrorism that was not related to FDI was statistically insignificant. Ref. [35] demonstrates the negative impact of terrorism on FDI only in highly corrupt countries. Ref. [36], in the Pakistan case, showed that terrorism has a negative, yet insignificant influence on FDI. Ref. [37] argues that terrorist incidents do not affect mergers and acquisitions (M\&A), while the intensity and frequency of terrorist attacks negatively affect M\&A. Interestingly, ref. [38] indicates that more terrorism led to more FDI in some of the regions and for the developing world as a whole. In other words, this means that terrorism encouraged FDI, especially in the 1990s.

When the research of the relationship among the observed variables is reduced to sectoral analysis and, in particular, to tourism, the results are even less pronounced. It is necessary to point out the research of [39] who on a panel of 57 countries, showed that institutional quality and democracies appear more important for FDI in services than general investment risk or political stability. In addition [40], by employing the panel of 50 countries they observed a positive impact of political violence on FDI in capital-intensive tertiary sector industries such as hotels and restaurants, transport, communications, real estate, etc. As far as tourism is concerned, only ref. [41] has shown that the impact of violent political turmoil on FDI in tourism cannot be confirmed by a clear link between the observed variables. Ref. [42] has pointed out, back in 1975, that there is an inadequate exemplification of the political component of research in tourism-related literature, while [43] in 1996 mentions the same issue. The scarcity of existing research related to issues of $F D I$ in tourism and terrorism is evident in the current decade [41,44], which implies the need for such research.

Although in recent years there has been a growing number of studies related to the issue of $F D I$ and terrorism, the study of terrorism as a determinant of attracting FDI in tourism is virtually unexplored. A review of the existing literature questions conventional wisdom that terrorism significantly reduces FDI in tourism [41]. Based on the foregoing and the fact that, according to the authors' knowledge, the study of terrorism as determinants of FDI in tourism has not been carried out so far, this justified the purpose of the research. 


\section{Methodological Framework and Data}

\subsection{Econometric Model and Estimation Method}

In this study, the baseline model is as follows:

$$
\begin{aligned}
\log F D I_{-} T / G D P_{i, t} & =a_{0}+a_{1} \log F D I \_T / G D P_{i, t-1}+a_{2} \log T E R R_{i, t} \\
& +a_{3} \log G D P \text { growth }_{i, t}+a_{4} \log \operatorname{INTARR}_{i, t}+\eta_{i}+\varepsilon_{i, t}
\end{aligned}
$$

where $i$ is the home country index, $t$ is the time index, $\alpha$ is the unknown parameter to be estimated, FDI_T/GDP is the ratio of FDI inflows in tourism to GDP, FDI_T/GDP (-1) is the lagged ratio of FDI inflows in tourism to GDP, TERR is the measure of international terrorism, GDPgrowth is GDP growth rate, INTARR is the number of international tourism arrivals, $\eta_{i}$ is the unobserved country-specific effect term and $\varepsilon_{i, t}$ is the usual error term.

The FDI share of tourism in GDP (FDI_T/GDP) was included as a dependent variable of the model. As independent model variables, the former level of FDI contribution to tourism in GDP (FDI_T/GDP $(-1)$ ), International Terrorism (INTTERR), GDP growth rate and the number of international tourist arrivals (INTARRs) were included. All of the variables are in logarithm forms.

In order to obtain more reliable research results, the model subsequently included the specific control variables:

$$
\begin{aligned}
& \log F D I \_T / G D P_{i, t}=a_{0}+a_{1} \log F D I \_T / G D P_{i, t-1}+a_{2} \log T E R R_{i, t} \\
& +a_{3} \log G D P g r o w t h_{i, t}+a_{4} \log {I N T A R R_{i, t}}_{1}+a_{5} \text { POLSTAB }_{i, t} \\
& +a_{6} \operatorname{CORR}_{i, t}+a_{7} \operatorname{DOINGBUS}_{i, t}+\eta_{i}+\varepsilon_{i, t}
\end{aligned}
$$

where POLSTAB is the index of Political Stability and Absence of Violence, CORR is the index of Control of Corruption and DOINGBUS is the Starting a business index, part of a Doing business index.

This research employed the System-Generalized Method of Moments (SYS-GMM) state-of-the-art econometric estimation method [45]. Early research of similar models used standard OLS techniques that are susceptible to the well-known spurious regression problem [46]. According to [47], "the pooled OLS estimator does not deal with either country-specific effects across the panel or endogeneity bias". Ref. [48] in 1982 introduced GMM. GMM is commonly used to study the dynamics of adjustment in samples with relatively large cross-sections and short time periods. The standard GMM estimator controls for measurement errors and endogeneity. On the other hand, it does not account for unobservable country-specific effects and can be vulnerable to inaccuracy due to small-sample bias.

The SYS-GMM estimator is developed by [49,50]. It produces more efficient and precise estimates compared to dynamic GMM by improving precision and reducing the finite sample bias [51] by allowing for more instruments [52]. This estimator resolves some of the small-sample biases of the standard GMM estimator without enforcing particularly strong assumptions [53]. This estimator creates a system of two equations; the first equation is differenced while the second one remains in levels [54]. Also, in addition to the corrections for serial correlations, measurement error and endogeneity also accounted for the underlying data dynamics [55]. The consistency of the SYS-GMM estimator depends on the validity of the instruments. To address this issue, two diagnostic tests were used to test the validity of the instruments, the Sargan test and the Hansen test.

\subsection{Empirical Data and Sample Selection}

The research was carried out based on annual time series for the period 2000 to 2016. The panel of research countries was made up of the following 50 countries: Australia, Austria, Belgium, Bosnia and Herzegovina, Bulgaria, Chile, China, Croatia, Czech Republic, Denmark, Estonia, Finland, France, Germany, Greece, Hong Kong, Hungary, Iceland, India, Ireland, Israel, Italy, Kazakhstan, Korea, Kosovo, Latvia, Lithuania, Luxembourg, Macedonia, Mauritius, Mexico, Morocco, Mozambique, Netherland, Norway, Poland, Portugal, Russia, Serbia, Slovak Republic, Slovenia, Spain, Sweden, 
Switzerland, Thailand, Tunisia, Turkey, United Kingdom, United States and Vietnam. The selection of this sample was made due to data availability of a dependent variable FDI inflow in tourism. However, this sample is sufficiently representative because the bulk of FDI in tourism is geared towards developed countries, i.e., 85-90 percent of TNC hotels are located in developed countries [56]. Out of a total of 145 destination countries of $F D I$ in tourism, the top five account for $30.2 \%$ of greenfield FDI in tourism projects, and the top 10 account for $45 \%$ of the project. This panel includes almost all of the top 10 host countries (except UAE). Additionally, although the risk of terrorism is by no means absent in developing countries, it appears to be primarily associated with industrialized countries [57]. The representativity of the sample is supported by the fact that it includes the top 10 world destinations as far as international tourist arrivals and international tourism receipts [2] are concerned. All 50 countries in the panel make up $72 \%$ of total international tourism receipts (see Appendix A). Summary statistics can be found in Appendix B.

The variable FDI in tourism (FDI_T) has been obtained from [58-60]. The variable is employed in millions of US dollars.

Data for terrorism derives from The Global Terrorism Database (GTD) [61]. This research used international total casualties as a terrorism variable. Total casualties include both injuries and fatalities (killed). The GTD database does not offer per se a column distinguishing domestic and international terrorist incidents. Decomposition was done following established methodology by $[62,63]$. Decomposition started with [62] five-step procedure. After this procedure had been exhausted, the process continued with the known perpetrator group identity parameter used by [63].

Starting a Business indicator was obtained from the Doing Business database [64]. All the other variables were obtained from [65].

Hypothesis 1. The level of FDI in tourism with a time lag of one period significantly affects the future FDI inflows in tourism.

The movement of one company may initiate a chain reaction of countermeasures at the domestic and international level by rivals who want to protect their positions [66]. In oligopolistic industries, companies will often imitate interaction because alternatives to imitation following the strategy of differentiation may prove to be costly and dangerous [67]. The related concept is so called "herding" [68]. "Herding" is essentially unscrupulous behavior based on the security of numbers; as long as everyone else behaves unconsciously, the probability of serious consequences for a particular company is low. Such behavior does not necessarily have to be regarded as irrational, i.e., "it is not that they are blind - this is simply the logical result of competitive processes in an oligopolistic industry" [69]. In the context of FDI, the idea of this perspective is that transnational corporations are largely doing what other companies are doing in the organization field when there is a high level of uncertainty [70].

Hypothesis 2. Terrorism has no significant impact on FDI in tourism.

After the terrorist attack in the US in 2001, terrorism became a source of concern for international investors and has entered the scene as a form of political risk [71,72]. The impact of political risk varies depending on which industry FDI is focused on. The research focused on sectoral differences is very modest and points to the specificity of particular industries [73,74]. Ref. [75], in one of the early reviews of research on the effect of political risk, concluded that empirical evidence is inconsistent and has mixed results related to the influence of political instability on FDI stocks or flows. Secondly, back to 1983, terrorism generally did not significantly affect FDI, although it had significant localized impacts in places such as the Basque region in Spain or Northern Ireland [31]. Finally, all further research leaves a shadow on the existence of such a postulate [33,76]. Ref. [41] explored the link between terrorism and FDI with the example of Egypt and amply warned on exaggeration connected with the negative impacts of terrorism on FDI in tourism. Finally, ref. [44] also points to a lack of existing 
research related to the $F D I$ in tourism and terrorism and concluded that the issues are very complex and that the impact of terrorism on FDI in tourism cannot be generalized. Since tourism demand and tourism supply are closely linked, it is logical to assume that if terrorism does not significantly affect the decline in tourist arrivals, there will be no downturn in tourism supply, i.e., FDI in tourism will not decline. The arguments in favour of the set hypothesis are as follows: according to the latest research, tourists are not too concerned about terrorism $[12,77,78]$, after the terrorist attack, tourism had already been recovering for 13 months [23], the latest UNWTO data show a continuous growth rate of international tourist arrivals [2], less significant and limited terrorist attacks have little impact on the expected returns of an investment project [33], out of 39 sectors, tourism is ranked 10th in terms of capital investment [79] and, above all, FDI in tourism continues to enter the countries affected by terrorism [80].

Hypothesis 3. The size of the market is an important determinant of FDI in tourism.

Market size is generally the most important determinant of FDI inflows. It is also a significant determinant of FDI in the services market [81]. The larger the market, the more likely it is that the investor will regain its fixed costs [82]. The size of the market is considered the most important location factor the investor considers when deciding on FDI [83]. The size of the overall economy market is measured by GDP. When the market size is small compared to other competitors in the country, such a market fails to attract FDI due to difficulty to achieve the economies of scale [84]. It should also be noted that the market size does not only apply to the domestic market, however also to the regional market in which the country is located. Corporations locate their FDI considering the regional context and context of the country as the country's attractiveness is limited by regional development characteristics [85]. Consequently, the main objective of regional political development has become attracting FDI [86]. The high economic growth affects the FDI inflows due to increased revenue and the effects of consumption $[87,88]$.

Hypothesis 4. The number of tourist arrivals significantly influences FDI in tourism.

Although indicators such as GDP or GDP per capita determine the market size, the more relevant measures for tourism would be the propensity to travel within the economy [89]. The level and the degree of tourism products and tourism development are important because FDI in tourism is under their influence [56]. The country will attract foreign investors to tourism if it has an effective tourism marketing strategy and promotional programs that are significantly funded [90]. Tourist arrivals and FDI are interconnected. Tourist arrivals are considered the main cause for FDI in tourism [91]. A large number of tourist arrivals in the country also indirectly complement the existing market, thus affecting the attraction of $F D I$ in the hotel industry $[56,92]$. The primary driver of service companies to invest abroad is based on tracking citizens and clients [93]. A significant number of studies have demonstrated the existence of a causal link between international tourist arrivals and FDI in tourism [94-99].

Hypothesis 5. Political stability and the absence of violence positively influence the FDI in tourism.

Political stability, along with macroeconomic stability, are key factors influencing the location decision of foreign investors. For every foreign investor, each country is the potential destination of its capital. However, given that every investor is a rational investor, one of the most important criteria when selecting a country in which to invest their capital is the investment risk. Generally, as long as the foreign investor believes it can operate profitably without excessive risk for its capital and staff, it will continue to invest. A host country with a high political risk will discourage FDI inflows into its market since the political volatility harms the profitability of $F D I$. The three major forms of political risk discourage FDI because of damage to their profitability and survival [100]: nationalization or expropriation of foreign assets (which is rare) and breach of contract (which is 
much more common) endanger foreign investment; political instability and arbitrary regulation in policies related to $F D I$ create uncertain investment environments and undermine the profitability of FDI; and political violence, including terrorist activities, can immediately damage foreign property and discourage productivity in the country for a long time.

Hypothesis 6. The higher level of corruption in the country negatively affects the FDI in tourism.

As corruption is widespread, less investor capital will flow to the country. Corrupt states are less likely to attract FDI in order to get assistance in the long-term economic development of the state. The amount of corruption in the country that foreign investors want to invest in sis as important as the cost of labor and the tax rate [101]. Corruption is occurring in countries where government transparency is low. Investors in these countries are either pulling or not investing at all, precisely because of the unstable political environment and inefficient bureaucracy and corruptive actions that ultimately damage the reputation of the investor and his profits. Lower levels of corruption leads to higher productivity of the sector [102,103].

Hypothesis 7. The ease of starting a business has a positive impact on FDI in tourism.

Starting a Business measures the paid-in minimum capital requirement, number of procedures, time and cost for a small- to medium-sized limited liability company to start up and formally operate in the economy's largest business city. The ranking of the Doing Business list indicates the attractiveness of the investment environment, where a higher position on the list means a more attractive investment environment. According to [104], a better ranking on Doing Business is significantly associated with higher $F D I$ inflow. In addition, countries with more effective regulations for starting a business have greater benefits from FDI inflows. According to [105], one step higher on the Doing Business scale can bring an additional $\$ 44$ million in FDI to the government.

\section{Research Results and Discussion}

The research results are summarised and presented in Tables 1 and 2. Table 1 presents the results from the Sargan's test and the Arellano-Bond AR(2) test. The p-value of the Sargan test is above 0.05, so the null hypothesis of the validity of instruments cannot be rejected. The results demonstrate the independence of the instruments from the residuals and, therefore, they are acceptable instruments. With regard to the Arellano-Bond test, there is no evidence of second-order serial correlation in the differenced error terms. The $p$-value of the aforementioned test is also above 0.05 , so the null hypothesis of the no second-order serial correlation cannot be rejected.

Table 1. SYS-GMM (System-Generalized Method of Moments) diagnostics.

\begin{tabular}{cc}
\hline Sargans's test & $28.16692(p=0.5090)$ \\
\hline Arellano-Bond second-order correlation test & $1.0709(p=0.2842)$ \\
\hline \multicolumn{2}{c}{ Source: Author calculations. }
\end{tabular}

Table 2. SYS-GMM estimation results.

\begin{tabular}{cc}
\hline Variables & Coefficient \\
\hline Lagged FDI_T/GDP share & $0.1404^{* * *}$ \\
International arrivals & $1.3261^{* * *}$ \\
Terrorism & 0.0221 \\
GDP growth $^{* * *}$ & $0.2247^{* *}$ \\
\hline te statistical significance at the $1 \%$ level. Source: Author calculations.
\end{tabular}


Table 2 shows the results of the SYS-GMM estimation. The results indicate a positive yet statistically insignificant impact of terrorism on FDI in tourism which is in accordance with the first research hypothesis. All of the other results are also in line with the set hypotheses. The international tourist arrivals, the lagged value of $F D I$ in tourism and the GDP growth have positive and highly significant coefficients.

For the countries in the panel, all of the variables have the expected sign. The main variable of interest is terrorism, however it is statistically insignificant. As far as the other variables are concerned, a $1 \%$ increase in the lagged value of FDI in tourism leads to an increase of $14 \%$ in the FDI in tourism inflow. Furthermore, according to the research results, a 1\% increase in international tourist arrivals leads to an increase of $132 \%$ in the FDI in tourism inflow. Lastly, a $1 \%$ increase in GDP growth leads to an increase of $22 \%$ in the FDI in tourism inflow.

An insignificant impact of terrorism on FDI in tourism is in line with the author's initial rational. Although it seems logical to assume that terrorism as a form of political risk [75] negatively affects $F D I$ in tourism, there are some researches that have already pointed to the fact that political risk does not necessarily affect $F D I[106,107]$. Recent research suggests that political risk can contribute to the FDI inflows [108] and that a higher rate of terrorism leads to a higher FDI growth, especially with regard to developing countries [38]. Moreover, ref. [40] has demonstrated the positive impact of political violence on FDI in capital-intensive tertiary sector industries such as hotels and restaurants, transportation, communications, real estate, etc.

Positive and significant impact of previous FDI levels on future FDI inflows is in line with existing research [109-111]. The presence of existing FDI is also a signal to potential investors that it is an environment in which it is possible to operate successfully. In other words, one lag length is needed to stimulate further FDI in tourism, i.e., the level of $F D I$ in the previous period encourages further growth of $F D I$ in tourism.

Research results related to the growth rate of GDP are also in line with previous research [112,113]. The positive GDP growth rate points to the market demand and higher market demand attracts further FDI inflow. It also signals the size of the potential market and the possibility of its expansion in the future which motivates foreign investors to start new investments.

International tourist arrivals is the determinant that has the most significant impact on the FDI inflow. These results are also in line with previous research [56,114]. Bearing in mind the interdependence of tourism demand and tourism supply, it is logical to expect that the growth of international tourist arrivals significantly influences $F D I$ in tourism.

Finally, the research results from the second proposed model with the control variables are summarised and presented in Tables 3 and 4. Table 3 presents the results from the Sargan's test and the Arellano-Bond AR(2) test. The p-value of the Sargan test is above 0.05, so the null hypothesis of the validity of instruments cannot be rejected. The results demonstrate the independence of the instruments from the residuals and, therefore, they are acceptable instruments. With regard to the Arellano-Bond test, there is no evidence of second-order serial correlation in the differenced error terms. The $p$-value of the aforementioned test is also above 0.05 , so the null hypothesis of the no second-order serial correlation cannot be rejected.

Table 3. SYS-GMM diagnostics.

\begin{tabular}{cc}
\hline Sargans's test & $19.76083(p=0.5980)$ \\
\hline Arellano-Bond second-order correlation test & $0.29344(p=0.7692)$ \\
\hline
\end{tabular}

Source: Author calculations. 
Table 4. SYS-GMM estimation results.

\begin{tabular}{|c|c|}
\hline Variables & Coefficient \\
\hline Lagged FDI_T/GDP share & 0.0812 \\
\hline International arrivals & $1.3475^{* * *}$ \\
\hline Terrorism & 0.1026 \\
\hline GDP growth & 0.0867 \\
\hline POLSTAB & 0.7482 \\
\hline CORR & -0.4070 \\
\hline DOINGBUSS & $0.0863^{* * *}$ \\
\hline
\end{tabular}

Table 4 shows the results of the SYS-GMM estimation. The results, although not all significant, are also strongly in accordance with the research hypotheses even when control variables are included in the model. The results indicate a positive yet statistically insignificant impact of terrorism on FDI in tourism. The international tourist arrivals and the ease of starting a business have positive and highly significant coefficients. The lagged value of $F D I$ in tourism, the GDP growth and the political stability have a positive yet insignificant impact, while corruption has a negative yet also insignificant impact.

For the countries in the panel, all of the variables have the expected sign. The very significant and positive influence on the further FDI inflow in tourism, even when the model includes control variables, still has the number of international tourist arrivals. According to the research results, a $1 \%$ increase in international tourist arrivals leads to an increase of $135 \%$ in the FDI in tourism inflow. As far as control variables are concerned, only the ease of starting a business is significant and therefore, a $1 \%$ increase in the Doing Business index leads to an increase of $8 \%$ in the FDI in tourism inflow. The significance of the Doing Business Index is in line with existing research results $[115,116]$. Better positioning of the country on the Doing Business list means a greater presence of global hotel chains in its economy [33]. Although the previous level of FDI in tourism has a positive impact on further FDI inflow into tourism, this determinant in the extended model is no longer significant. In other words, previous FDI in tourism has no significant impact on future FDI in tourism. Political stability and corruption are also not significant determinants that affect the future FDI in tourism and such results are consistent with previous studies $[107,117]$.

\section{Concluding Remarks}

Starting from the fact that, according to the authors' knowledge, there is no research that examines terrorism as a determinant of attracting FDI in tourism, and that the results of previous research related to the importance of terrorism as a determinant of attracting total FDI are not unambiguous, the gap in the existing research is recognized. Given the abovementioned, the impact of terrorism on attracting FDI in tourism was explored using the panel of 50 countries for the period from 2000 to 2016. In addition to terrorism, three additional variables, the previous FDI level, the GDP growth rate and the number of international tourist arrivals, were included in the analysis. In order to obtain more reliable research results, the proposed model was expanded with additional control variables.

The example of a panel of countries has shown that terrorism is not a significant determinant of FDI in tourism. Such a result is expected and is consistent with the most recent research [41,44]. The significance of the previous FDI level, the GDP growth rate and the number of international tourist arrivals are in line with well-established and multiple proven theoretical points of reference which are considered extremely important determinants of $F D I$ attraction $[70,81,87,89]$. All three underlying determinants positively and significantly affect the further inflow of $F D I$ in tourism at a $1 \%$ level of significance. Looking at another model that has been expanded with certain control variables, it is possible to conclude that for the further FDI inflow in tourism, the most important is the further increase in the number of international tourist arrivals and the easier business conditions in the country. This is evidence that there are other factors that play a much more important role than terrorist risk when it comes to attracting foreign investors [118]. In the model with control variables, the GDP 
growth rate, the previous level of $F D I$, political stability and corruption are not significant determinants of attracting FDI in tourism. According to ref. [119], the encouraging macroeconomic conditions, the political stability, the elimination of administrative and legislative barriers, the elimination of the image of the country as a corrupt destination and tourism staff education at all levels are particularly important for $F D I$ in tourism. Nevertheless, political stability alone is not a guarantee of investment safety either in tourism or in any other part of the economy, especially in the absence of favorable economic conditions [120].

Knowing how tourism is rapidly recovering from terrorism [23] and taking into account the latest data from the market which show that FDI in tourism continues to enter the countries affected by terrorism [80], the obtained results are not surprising. The global hotel chains are the main providers of FDI in tourism, and corporations learned to handle and incorporate the risk of terrorism into their business in the 80's of the last century [121]. It is not to be overlooked and there is the possibility that the presence of global corporations in tourism can in fact help to restore trust in tourist destinations affected by terrorism [122]. Refs. [82,123] have shown that FDI, as part of economic globalization, has an adverse negative impact on transnational terrorism. In addition, contemporary thoughts suggest that terrorism will not stop further globalization [19].

According to the author's knowledge, the main contribution of this paper is that this is the first quantitative research that observes terrorism as a determinant of attracting FDI in tourism. Considering on the one hand the significance of $F D I$ for the further development of tourism, especially in developing and less developed countries, and on the other hand, terrorism as a real threat to the further expansion of global business, such a contribution is of utmost importance. It should be highlighted as a particularly important contribution that the obtained research results point out that terrorism is not a significant determinant of attracting FDI in tourism and, as such, raises a serious foundation for future political action. Although the global political challenge is to keep terrorism under control and to annul it in the long run, foreign investors in tourism are primarily attracted by the growth rates of tourist arrivals and the business conditions in the country. Research results significantly contribute to the consideration of sustainability because they point to the fact that terrorism has not become a serious obstacle to further sustainable development, given the role that FDI and tourism can play in this area. Further FDI are directly linked to the achievement of global sustainable development goals [124] as they have the potential to create new jobs, increase production capabilities, lead to technology transfer, etc. Nevertheless, tourism also has a significant role in the achievement of the 2030 Agenda for Sustainable Development. The combined forces of FDI and tourism overcome the insecurity that terrorism entails and are a successful platform for contributing to sustainable development.

The research results may have significant implications for policy-makers. Competitive further development of tourism, especially in developing and less developed countries, requires investment in capital, infrastructure, knowledge and availability of global marketing and distribution chains. FDI in this area can play a significant role and most commonly appears in the form of global hotel chain expansion [56]. Such global hotel chains have a superior marketing and promotional effect because they are linked to global distribution systems, leading to production and qualitative effects in the host country because the presence of the global brand is a certain guarantee of service standards and, perhaps most importantly, the transfer of soft technology in the form of improving managerial expertise in the host country. Thus, further uninterrupted development of tourism inevitably requires attracting foreign investors as one of the pillars of the sustainable development of the global economy [5]. The research results suggest that policies aimed at attracting investors in tourism primarily need to ensure better business conditions in the country. Nevertheless, it is up to the political authorities to provide both security and preventive measures against terrorism that will maintain the threat of terrorism at the lowest possible level in the national, regional and international environment. The World Tourism Organization's recommendation is to "develop a national policy on tourism safety commensurate with the prevention of visitor risks" [125]. Absolute levels of instability and rates of violence in tourism are less important than the perceived uncertainty of potential tourists [126]. Adequate security and 
preventive measures ensure that tourists perceive the destination as safe from terrorism. A direct consequence of an adequate political response to terrorism is the further development of tourism demand which, according to economic logic, encourages further tourist supply or, in this context, FDI in tourism inflows.

Funding: This research was funded by the University of Rijeka grant number ZN UNIRI 8/16.

Acknowledgments: The author would like to thank the anonymous referees for helpful suggestions and comments.

Conflicts of Interest: The author declares no conflict of interest.

\section{Appendix A.}

Table A1. International tourism receipts (million).

\begin{tabular}{|c|c|c|c|c|c|}
\hline Country & Year & Country & Year & Country & Year \\
\hline Australia & 32.423 & Iceland & 2.415 & Norway & 5.205 \\
\hline Austria & 19.300 & India & 22.427 & Poland & 10.977 \\
\hline Belgium & 11.839 & Ireland & 5.186 & Portugal & 14.036 \\
\hline Bosnia and Herzegovina & 709 & Israel & 5.722 & Russia & 7.788 \\
\hline Bulgaria & 3.634 & Italy & 40.246 & Serbia & 1.151 \\
\hline Chile & 2.737 & Kazakhstan & 1.549 & Slovak Republic & 2.748 \\
\hline China & 44.432 & Korea & 17.210 & Slovenia & 2.424 \\
\hline Croatia & 9.634 & Kosovo & & Spain & 60.346 \\
\hline Czech Republic & 6.309 & Latvia & 867 & Sweden & 12.614 \\
\hline Denmark & 6.877 & Lithuania & 1.185 & Switzerland & 15.937 \\
\hline Estonia & 1.536 & Luxembourg & 4.292 & Thailand & 49.871 \\
\hline Finland & 2.717 & Macedonia & 285 & Tunisia & 1.239 \\
\hline France & 42.481 & Mauritius & 1.572 & Turkey & 18.743 \\
\hline Germany & 37.433 & Mexico & 19.571 & United Kingdom & 39.615 \\
\hline Greece & 14.618 & Morocco & 6.548 & United States & 205.940 \\
\hline Hong Kong & 32.860 & Mozambique & 108 & Vietnam & 8.250 \\
\hline \multirow[t]{4}{*}{ Hungary } & 5.653 & Netherland & 14.054 & & \\
\hline & & & & Total & 875.313 \\
\hline & & & & World & 1220.000 \\
\hline & & & & Panel share & $72 \%$ \\
\hline
\end{tabular}

Source: Author calculations according to [2].

\section{Appendix B.}

Table A2. Summary statistics.

\begin{tabular}{cccccc}
\hline Variable & Obs & Mean & Std. Dev. & Min & Max \\
\hline FDI_T/GDP & 574 & $4.13 \times 10^{-9}$ & $2.00 \times 10^{-8}$ & 0 & $2.96 \times 10^{-7}$ \\
TERR & 850 & 38.09765 & 621.4515 & 0 & 17840 \\
GDP growth & 849 & 3.268843 & 3.63209 & -14.81416 & 26.97392 \\
INTARR & 829 & $1.33 \times 10^{7}$ & $1.75 \times 10^{7}$ & 99000 & $8.45 \times 10^{7}$ \\
POLSTAB & 793 & 0.4091093 & 0.780753 & -1.99828 & 1.760102 \\
CORR & 800 & 0.7119057 & 1.009065 & -1.177213 & 2.469991 \\
DOINGBUS & 524 & 83.72101 & 10.04922 & 41.53 & 98.12 \\
\hline
\end{tabular}

Source: Author calculations.

\section{References and Note}

1. Lashkarizadeh, M.; Keshmir, Z.; Gashti, H.P. Evolution of the Relationship between Tourism Industry and Economic Growth in Iran. Asian J. Bus. Manag. Sci. 2012, 1, 88-97. 
2. UNWTO. UNWTO World Tourism Barometer. 2018. Available online: http://cf.cdn.unwto.org/sites/all/ files/pdf/unwto_barom18_01_january_excerpt_hr.pdf (accessed on 18 July 2018).

3. WTTC. Travel \& Tourism Global Economic Impact and Issues 2018. 2018. Available online: https:/ / www.wttc.org/-/media/files/reports/economic-impactresearch/documents-2018/globaleconomic-impact-and-issues-2018-eng.pdf (accessed on 25 June 2018).

4. Chen, L.; Devereux, J. Tourism and welfare in Sub-Saharan Africa: A theoretical analysis. J. Afr. Econ. 1999, 8, 209-227. [CrossRef]

5. Shehadi, S. On a Journey: Tourism Takes a New Turn towards Sustainable Development. 2017. Available online: https: / /www.FDIintelligence.com/Sectors/Hotels-Tourism/On-a-journey-tourism-takes-a-newturn-towards-sustainable-development (accessed on 14 June 2018).

6. Endo, K. Foreign direct investment in tourism-Flows and volumes. Tour. Manag. 2006, 27, 600-614. [CrossRef]

7. Salleh, N.H.M.; Othman, R.; Sarmidi, T. An Analysis of the Relationships between Tourism Development and Foreign Direct Investment: An Empirical Study in Selected Major Asian Countries. Int. J. Bus. Soc. Sci. 2011, 3, 250-257.

8. Romero, L. New Data Shows Terror Attacks Are Becoming Less Frequent and Much Less Deadly. 2018. Available online: https:/ / qz.com/1346205/the-global-terrorism-database-shows-attacks-are-becomingless-frequent-and-deadly/ (accessed on 30 September 2018).

9. Tang, S.; Selvanathan, S.; Selvanathan, S. The relationship between foreign direct investment and tourism: Empirical evidence from China. Tour. Econ. 2007, 13, 25-39. [CrossRef]

10. Davidson, L.; Sahli, M. Foreign direct investment in tourism, poverty alleviation, and sustainable development: A review of the Gambian hotel sector. J. Sustain. Tour. 2015, 23, 167-187. [CrossRef]

11. Hunter-Jones, P.; Jeffs, A.; Smith, D. Backpacking Your Way into Crisis. J. Travel Tour. Mark. 2008, $23,2-4$. [CrossRef]

12. Larsen, S.; Brun, W.; Øgaard, T. What tourists worry about: Construction of a scale measuring tourist worries. Tour. Manag. 2009, 30, 260-265. [CrossRef]

13. Muzindutsi, P.F.; Manaliyo, J.C. Effect of Political Risk Shocks on Tourism Revenue in South Africa: Time Series Analysis. Int. J. Bus. Manag. Stud. 2016, 8, 170-186.

14. Giddens, A.; Pierson, C. Conversations with Giddens: Making Sense of Modernity; Stanford University Press: Palo Alto, CA, USA, 1998.

15. Jain, S.C.; Grosse, R. Impact of Terrorism and Security Measures on Global Business Transactions: Some International Business Guidelines. J. Transnatl. Manag. 2009, 14, 42-73. [CrossRef]

16. Khiun Then, S.; Loosemore, M. Terrorism prevention, preparedness, and response in built facilities. Facilities 2006, 24, 157-176. [CrossRef]

17. Doggrell, K. This is More Threatening to Hotel Revenue than Terror Attacks. 2017. Available online: https: / / www.hotelmanagement.net/own/more-threatening-to-hotelrevenue-than-terror-attacks (accessed on 22 April 2018).

18. EIU. Risk 2018 Planning for an Unpredictable Decade, an Economist Intelligence Unit Report. 2008. Available online: http:/ /graphics.eiu.com/upload/BT_RISK.pdf (accessed on 5 May 2018).

19. Gerber, J. International Economics; Pearson Education Limited: London, UK, 2018.

20. Oaten, S.; Le Quesne, K.; Segal, H. The Travel \& Tourism Competitiveness Report 2015: Growth through Shocks. 2015. Available online: http:/ / www3.weforum.org/docs/TT15/WEF_Global_Travel\&Tourism_ Report_2015.pdf (accessed on 30 June 2018).

21. Agrawal, S. The Impact of Terrorism on Foreign Direct Investment: Which Sectors Are More Vulnerable? Available online: http:/ / scholarship.claremont.edu/cmc_theses/124 (accessed on 17 May 2016).

22. Bharwani, S.; Mathews, D. Risk identification and analysis in the hospitality industry: Practitioners' perspectives from India. Worldw. Hosp. Tour. Themes 2012, 4, 410-427. [CrossRef]

23. Zillman, C. Terrorism's Effect on Tourism Doesn't Last Very Long. Fortune. 2015. Available online: http: / / fortune.com/2015/11/30/terrorism-tourism-paris/ (accessed on 22 June 2016).

24. Enders, W.; Todd, S. Terrorism and Foreign Direct Investment in Spain and Greece. Kyklos 1996, 49, 331-352. [CrossRef]

25. Abadie, G.; Gardeazabal, J. The economic costs of conflicts: A case study of the basque country. Am. Econ. Rev. 2003, 93, 113-132. [CrossRef] 
26. Abadie, A.; Gardeazabal, J. Terrorism and the world economy. Eur. Econ. Rev. 2008, 52, 1-27. [CrossRef]

27. Alomar, M.; El-Sakka, T. The Impact of Terrorism on the FDI Inflows to Less Developed Countries: A Panel Study. Eur. J. Econ. Finance Adm. Sci. 2011, 28, 116-125.

28. Bezić, H.; Galović, T.; Mišević, P. The impact of terrorism on the FDI of the EU and EEA Countries. Proc. Rij. Sch. Econ. 2016, 34, 333-362. [CrossRef]

29. Akhtar, Z.; Yasin, H. Terrorism and Political Instability Implications for Foreign Direct Investment: A Case Study of South and South East Asian Countries. Pak. J. Appl. Econ. 2015, 25, 67-98.

30. Shah, M.H.; Faiz, M. Terrorism and foreign direct investment: An empirical analysis of SAARC countries. City Univ. Res. J. 2015, 5, 219-233.

31. Crenshaw, M. Introduction: Reflections on the Effects of Terrorism. In Terrorism, Legitimacy, and Power: The Consequences of Political Violence; Crenshaw, M., Ed.; Wesleyan University Press: Middletown, CT, USA, 1983.

32. Enders, W.; Sachsida, A.; Todd, S. The Impact of Transnational Terrorism on U.S. Foreign Direct Investment. Political Res. Q. 2006, 59, 517-531. [CrossRef]

33. Li, Q. Political violence and foreign direct investment. In Regional Economic Integration, Research in Global Security Management; Fratianni, M., Ed.; Emerald Group Publishing Limited: Bingley, UK, 2006; Volume 12, pp. 225-249.

34. Powers, M.; Choi, S.W. Does Transnational Terrorism Reduce Foreign Direct Investment? Business-Related Versus non-Business-Related Terrorism. J. Peace Res. 2012, 49, 407-422. [CrossRef]

35. Efobi, U.; Asongu, S.; Beecroft, I. Foreign Direct Investment, Aid and Terrorism: Empirical Insight Conditioned on Corruption Control; Working Paper No. 15/007; African Governance and Development Institute: Yaoundé, Cameroon, 2015.

36. Rauf, S.; Mehmood, R.; Rauf, A.; Mehmood, S. Integrated Model to Measure the Impact of Terrorism and Political Stability on FDI Inflows: Empirical Study of Pakistan. Int. J. Econ. Finance 2016, 8. [CrossRef]

37. Quyang, A.Y.; Rajan, R.S. Impact of terrorism on cross-border mergers and acquisitions (M\&As): Prevalence, frequency and intensity. Open Econ. Rev. 2016, 1-28. [CrossRef]

38. Lutz, B.J.; Lutz, J.M. Globalization and the Economic Consequences of Terrorism; Palgrave Macmillan: London, UK, 2017.

39. Kolstad, I.; Villanger, E. Determinants of Foreign Direct Investment in Services. Eur. J. Political Econ. 2008, 24, 518-533. [CrossRef]

40. Mihalache, A. Who's afraid of political violence? Evidence from industry-level FDI flows. In Proceedings of the Annual Meeting of the Theory vs. Policy? Connecting Scholars and Practitioners, New Orleans, LA, USA, 17-20 February 2010. Available online: http:/ / citation.allacademic.com/meta/p413893_index.html (accessed on 17 May 2016).

41. Steiner, C. An overestimated relationship? Violent political unrest and tourism foreign direct investment in the Middle East. Int. J. Tour. Res. 2010, 12, 726-738. [CrossRef]

42. Mathews, H.G. International tourism and political science research. Ann. Tour. Res. 1975, 2, $195-203$. [CrossRef]

43. Fornica, S. Political risk analysis in relation to foreign direct investment: A view from the hospitality industry. Tour. Rev. 1996, 51, 15-23. [CrossRef]

44. Nikšić Radić, M.; Barišić, M. Does Terrorism have a Limited Impact on International Investments in Tourism? Some Theoretical Considerations. Almatourism J. Tour. Cult. Territ. Dev. 2018, 9, 153-164.

45. De Vita, G.; Kyaw, K.S. Tourism development and growth. Ann. Tour. Res. 2016, 60, 23-26. [CrossRef]

46. Ghali, M.A. Tourism and Economic Growth: An Empirical Study. Econ. Dev. Cult. Chang. 1976, 24, 527-538. [CrossRef]

47. De Vita, G.; Kyaw, K.S. Tourism Specialization, Absorptive Capacity and Economic Growth. J. Travel Res. 2016, 1-13. [CrossRef]

48. Hansen, L.P. Large Sample Properties of Generalized Method of Moments Estimators. Econometrica 1982, 50, 1029-1054. [CrossRef]

49. Arellano, M.; Bover, O. Another look at the instrumental variable estimation of error-components models. J. Econ. 1995, 68, 29-51. [CrossRef]

50. Blundell, R.; Bond, S. Initial Conditions and Moment Restrictions in Dynamic Panel Data Models. J. Econ. 1998, 87, 115-143. [CrossRef]

51. Baltagi, B.H. Econometric Analysis of Panel Data, 4th ed.; John Wiley \& Sons Ltd.: Chichester, UK, 2008. 
52. Roodman, D. How to do xtabond2: An Introduction to Difference and System GMM in Stata. Stata J. 2009, 9, 86-136. [CrossRef]

53. Bond, S.; Windmeijer, F. Finite Sample Inference for GMM Estimators in Linear Panel Data Models; CEMMAP Working Paper No. CWP04/02; Institute for Fiscal Studies: London, UK, 2002.

54. Kurul, Z.; Yalta, A.Y. Relationship between Institutional Factors and FDI Flows in Developing Countries: New Evidence from Dynamic Panel Estimation. Economies 2017, 5, 17. [CrossRef]

55. De Vita, G. The long-run impact of exchange rate regimes on international tourism flows. Tour. Manag. 2014, 45, 226-233. [CrossRef]

56. UNCTAD. FDI in Tourism: The Development Dimension. (Barrowclough, Diana and Miroux, Anne and Mirza, Hafiz and others, Ed. UNCTAD. 2007. Available online: http://unctad.org/en/Docs/iteiia20075_en. pdf (accessed on 10 January 2011).

57. Re, S. Terrorism Risk Still Looms Large. 2010. Available online: http://www.swissre.com/rethinking/ Terrorism_risk_still_looms_large.html (accessed on 16 September 2018).

58. OECD. International Direct Investment Database (Data File). 2018. Available online: https://stats.oecd.org/ Index.aspx?DatasetCode=FDI_FLOW_INDUSTRY (accessed on 8 January 2018).

59. UNCTAD. Industrial FDI statistics data obtained internally by email Astrit.Sulstarova@unctad.org. 2018

60. Vienna Institute for International Economic Studies Databases. Available online: https:// data.wiiw.ac.at/ FDI-database.html (accessed on 30 May 2018).

61. START. Global Terrorism Database (Data File). 2018. Available online: https://www.start.umd.edu/gtd (accessed on 8 January 2018).

62. Enders, W.; Sandler, T.; Gaibulloev, K. Domestic versus transnational terrorism: Data, decomposition, and dynamics. J. Peace Res. 2011, 48, 319-337. [CrossRef]

63. Kis-Katos, K.; Liebert, H.; Schulze, G.G. On the origin of domestic and international terrorism. Eur. J. Political Econ. 2011, 27, S17-S36. [CrossRef]

64. Doing Business Database. 2018. Available online: https://datacatalog.worldbank.org/dataset/doingbusiness (accessed on 9 September 2018).

65. World Bank Open Data. 2018. Available online: https://data.worldbank.org/ (accessed on 30 May 2018).

66. Schenk, H. Large Mergers a Matter of Strategy Rather than Economics, Text Box Prepared for the UNCTAD's World Investment Report 1999. 1999. Available online: http:/ / www2.econ.uu.nl/users/schenk/WIR99.html (accessed on 15 January 2015).

67. Lieberman, M.B.; Asaba, S. Why do firms imitate each other. Acad. Manag. Rev. 2006, 31, 366-385. [CrossRef]

68. Hoenen, A.K.; Hansen, M.W. Oligopolistic Competition and Foreign Direct Investment-(Re) Integrating the Strategic Management Perspective in the Theory of Multinational Corporations; Department of Intercultural Communication and Management, Copenhagen Business School: Frederiksberg, Denmark, 2009.

69. Lung, Y. Is the Rise of Emerging Countries as Automobile Producers an Irreversible Phenomenon. In Global Strategies and Local Realities: The Auto Industry in Emerging Markets; Humphrey, J., Lecler, Y., Salerno, M., Eds.; London \& St Martin's Press: New York, NY, USA, 2000.

70. Westney, D.E. Institutional Theory and the Multinational Corporation. In Organization Theory and the Multinational Corporation, 2nd ed.; Ghoshal, S., Westney, E., Eds.; St. Martin's Press: New York, NY, USA, 2001.

71. Berry, C. The Convergence of the Terrorism Insurance and Political Risk Insurance Markets for Emerging Market Risk: Why It Is Necessary and How It Will Come About. In International Political Risk Management: Needs of the Present, Challenges for the Future; Moran, T.H., West, G.T., Martin, K., Eds.; The World Bank: Washington, DC, USA, 2007; pp. 13-35.

72. Lee, C. Terrorism, Counterterrorism Aid, and Foreign Direct Investment. Foreign Policy Anal. 2017, 13, 168. [CrossRef]

73. Blanton, S.L.; Blanton, R. Rights, Institutions, and Foreign Direct Investment: An Empirical Assessment. Foreign Policy Anal. 2012, 8, 431-452. [CrossRef]

74. Dunning, J. International Production and the Multinational Enterprise; Allen \& Unwin: London, UK, 1981.

75. Kobrin, S.J. Political risk: A review and reconsideration. J. Int. Bus. Stud. 1979, 10, 67-80. [CrossRef]

76. Olibe, K.O.; Crumbley, C.L. Determinants of US private foreign direct investments in OPEC nations: From public and non-public policy perspectives. J. Public Budgeting, Account. Financial Manag. 1997, 9, 331-355. [CrossRef] 
77. Wolff, K.; Larsen, S. Can terrorism make us feel safer? Risk perceptions and worries before and after the July 22nd attacks. Ann. Tour. Res. 2014, 44, 200-209. [CrossRef]

78. Wolff, K.; Larsen, S. A Taxonomy of Terror-About the Effect of Different Kinds of Terror on Risk Perceptions. Scand. J. Hosp. Tour. 2017, 17, 111-128. [CrossRef]

79. Fingar, C. Inside FDI: Why the Tourism Industry is Finally Going Places. 2017. Available online: https:/ / www. FDIintelligence.com/Inside-FDI/Inside-FDI-Why-thetourism-industry-is-finally-going-places (accessed on 29 May 2018).

80. Shehadi, S. Tunisia Back on the Tourism Trail. 2018. Available online: https://www.FDIintelligence.com/ Sectors/HotelsTourism/On-a-journey-tourism-takes-a-new-turn-towards-sustainable-development (accessed on 2 November 2018).

81. Banga, R. Foreign Direct Investment in Services: Implication for Developing Countries. Asia-Pac. Trade Invest. Rev. 2005, 1, 55-72.

82. Navaretti, G.B.; Venables, A.; Barry, F. Multinational Firms in the World Economy; Princeton University Press: Princeton, NJ, USA, 2004.

83. Gara, J. Foreign Direct Investment in Africa; Current Studies No. 28; United Nations: New York, NY, USA, 1995.

84. Van Wyk, J.; Lal, A.K. Risk and FDI inflows to developing countries. South Afr. J. Econ. Manag. Sci. 2008, 11, 511-527. [CrossRef]

85. UNCTAD. Transnational Corporations, and the Infrastructure Challenge. UNCTAD, 2008. Available online: https:/ / unctad.org/en/Docs/wir2008_en.pdf (accessed on 8 January 2018).

86. Lovering, J. MNCs and wannabes-Inward investment discourses of regional development and the regional services class. In The New Competition for Inward Investment: Companies, Institutions and Territorial Development; Phelps, N., Raines, P., Eds.; Edward Elgar Publishing: Cheltenham, UK, 2003; pp. 39-78.

87. Dornean, A.; Işan, V.; Oanea, D.C. The Impact of the Recent Global Crisis on Foreign Direct Investment. Evidence from Central and Eastern European Countries. Procedia Econ. Finance 2012, 3, 1012-1017. [CrossRef]

88. Hecock, R.D.; Jepsen, E.M. Should Countries Engage in a Race to the Bottom? The Effect of Social Spending on FDI. World Dev. 2013, 44, 156-164. [CrossRef]

89. Nansongole, N.E. Determinants of Foreign Direct Investment in Tourism: The Case of Malawi. Master's Thesis, North-West University, Vanderbijlpark, South Africa, 2011.

90. Yunis, E. Attracting FDI with good CSR practices in the tourism sector. In Responsible Enterprise, Foreign Direct Investment and Investment Promotion: Key Issues in Attracting Investment for Sustainable Development; Dufey, A., Grieg-Gran, M., Ward, H., Eds.; International Institute for Environment and Development: London, UK, 2008.

91. Agarwal, M.K.; Upadhyay, R.P. Tourism and Economic Development in Nepal; Northern Book Centre: New Delhi, India, 2006.

92. Pham, H.M. FDI and Development in Vietnam: Policy Implication; Institute of South East Asian Studies: Singapore, 2004.

93. Yu, L. The International Hospitality Business: Management and Operations; The Haworth Hospitality Press: New York, NY, USA, 1999.

94. Dunning, J.; Kundu, S.K. Impact of Transnational Hotel Chains and Management Companies Operating in Developing Countries u Transnational Corporations in International Tourism. 1982. Available online: http:/ / unctc.unctad.org/data/e82iia9b.pdf (accessed on 10 July 2013).

95. Katircioglu, S.T. Revisiting the tourism-led-growth hypothesis for Turkey using the bounds test and Johansen approach for cointegration. Tour. Manag. 2009, 30, 17-20. [CrossRef]

96. Selvanathan, S.; Selvanathan, E.A.; Viswanathan, B. Foreign Direct Investment and Tourism: Empirical Evidence from India. Tour. Anal. 2012, 17, 91-98. [CrossRef]

97. Othman, R.; Salleh, N.H.M.; Sarmidi, T. Analysis of Causal Relationship Between Tourism Development, Economic Growth and Foreign Direct Investment: An ARDL Approach. J. Appl. Sci. 2012, 12, 1245-1254. [CrossRef]

98. Samimi, A.J.; Sadeghi, S.; Sadeghi, S. The Relationship between Foreign Direct Investment and Tourism Development: Evidence from Developing Countries. Int. J. Inst. Econ. 2013, 5, 59-68.

99. Perić, J.; Nikšić Radić, M. FDI-led tourism growth hypothesis: Empirical evidence from Croatian tourism. Eur. J. Tour. Hosp. Recreat. 2016, 7, 168-175. [CrossRef]

100. Baek, K.; Qian, X. An analysis on political risks and the flow of foreign direct investment in developing and industrialized economies. Econ. Manag. Financ. Mark. 2011, 6, 60-91. 
101. Smarzynska, B.K.; Wei, J. Corruption and Composition of FDI: Firm Level Evidence; Policy Research Working Paper No. 2360; World Bank: Washington, DC, USA, 2000; pp. 18-23.

102. Tondl, G.; Fornero, J.A. Sectoral Productivity and Spillover Effects of FDI in Latin America; FIW Working Paper 53; Europainstitut, Wirtschaftsuniversitat Wien: Wien, Austria, 2008.

103. Meyer, K.A.; Sinani, E. When and where does foreign direct investment generate positive spillovers? A meta-analysis. J. Int. Bus. Stud. 2009, 40, 1075-1094. [CrossRef]

104. Piwonski, K. Does the 'Ease of Doing Business' in a Country Influence Its Foreign Direct Investment Inflows; Bryant University: Smithfield, RI, USA, Unpublished paper; 2010.

105. Jayasinghe, U. Sri Lanka Needs to Be Better than India in FDI battle: IMF. 2011. Available online: http:/ / www. ft.lk/2011/07/22/sri-lanka-needs-to-be-better-than-india-in-FDI-battle-imf $\backslash \mathrm{T} 1 \backslash$ textgreater $\{$ (accessed on 22 July 2014).

106. Chase, C.D.; Kuhle, J.L.; Walther, C.H. The relevance of political Risk in Direct Foreign Investment. Manag. Int. 1988, 28, 31-38.

107. Fatehi-Sedeh, K.; Safizadeh, H.M. Sociopolitical events and foreign direct investment: American investments in South and Central American countries. J. Manag. 1988, 14, 93-107.

108. Tosun, M.; Yurdakul, M.; Varol İyidoğan, P. The Relationship between Corruption and Foreign Direct Investment Inflows in Turkey: An Empirical Examination. Transylv. Rev. Adm. Sci. 2014, 42E, 247-257.

109. Brzozowski, M. Exchange Rate Variability and Foreign Direct Investment-Consequences of EMU Enlargement; CASE Network Studies and Analyses 0258; CASE-Center for Social and Economic Research: Warsaw, Poland, 2003.

110. Kumar, P. Macroeconomic uncertainty and FDI in developing countries. Theor. Appl. Econ. 2018, XXV, 15-30.

111. Economou, F.; Hassapis, C.; Philippas, N.; Tsionas, M. Foreign Direct Investment Determinants in OECD and Developing Countries. Rev. Dev. Econ. 2016, 21, 527-542. [CrossRef]

112. Al Nasser, O.M. How does foreign direct investment affect economic growth? The role of local conditions. Lat. Am. Bus. Rev. 2010, 11, 111-139. [CrossRef]

113. Mohamed, S.E.; Sidiropoulos, M.G. Another look at the determinants of foreign direct investment in MENA countries: An empirical investigation. J. Econ. Dev. 2010, 35, 75-95.

114. Snyman, J.A.; Saayman, M. Key factors influencing direct investment in tourism industry in South Africa. Tour. Rev. 2009, 64, 49-58. [CrossRef]

115. Bayraktar, N. Foreign Direct Investment and Investment Climate. Procedia Econ. Finance 2013, 5, 83-92. [CrossRef]

116. Olival, A. The influence of Doing Business' institutional variables in Foreign Direct Investment, No 0048, GEE Papers, Gabinete de Estratégia e Estudos, Ministério da Economia. 2012. Available online: https: / / EconPapers.repec.org/RePEc:mde:wpaper:0048 (accessed on 15 May 2018).

117. Sethi, D.; Guisinger, S.; Phelan, S.; Berg, D. Trends in Foreign Direct Investment Flows: A Theoretical and Empirical Analysis. J. Int. Bus. Stud. 2003, 34, 315-326. [CrossRef]

118. Ullah, M.S.; Inaba, K. Liberalization and FDI Performance: Evidence from ASEAN and SAFTA Member Countries. J. Econ. Struct. 2014, 3. [CrossRef]

119. Perić, J.; Nikšić Radić, M. Macroeconomic Environment and Greenfield Foreign Direct Investment of Hotel Brands. Èkon. Vjesn. 2016, 29, 468-485.

120. Lewis, M. Does political instability in developing countries affect foreign investment flow? Manag. Int. Rev. $1979,19,59-68$.

121. Ryans, J.K.; Shanklin, W.L. How Managers Cope with Terrorism. Calif. Manag. Rev. 1980, $23,66-72$. [CrossRef]

122. Hitchcock, M.; Darma Putra, I. The Bali bombings: Tourism crisis management and conflict avoidance. Curr. Issues Tour. 2005, 8, 62-76. [CrossRef]

123. Li, Q.; Schaub, D. Economic Globalization and Transnational Terrorism A Pooled Time-Series Analysis. J. Confl. Resolut. 2004, 48, 230-258. [CrossRef]

124. United Nations Global Compact. What do the UN Sustainable Development Goals Mean for Investors? 2016. Available online: https://sdg-investments.com/fileadmin/user_upload/pri-sdg-relation.pdf (accessed on 10 August 2018). 
125. Haddad, C.; Nasr, A.; Ghida, E.; Ibrahim, H.A. How to Re-Emerge as a Tourism Destination after a Period of Political Instbility; The Travel and Tourism Competitiveness Report; World Economic Forum: Geneva, Switzerland, 2015; pp. 53-57.

126. Richter, L.K. Political Instability and Tourism in the Third World. In Tourism and the Less Developed Countries; Harrison, D., Ed.; Belhaven Press: London, UK, 1992; pp. 35-46. 